\title{
Prognostic Factors in Prostate Cancer: \\ A Review Article
}

\author{
Dr. S. A. Adewuyi. MBBS, MCPS, FCPS, FMCR, FWACS, FICS. \\ Dr. I. C. Akpayak MBBS. \\ Radiotherapy and Oncology Department, \\ Ahmadu Bello University Teaching Hospital, Shika-Zaria. \\ Surgery Department (Urology unit) \\ Jos University Teaching Hospital \\ Jos. \\ Correspondence: \\ Dr. S. A. Adewuyi MBBS, MCPS, FCPS, FMCR, FWACS, FICS. \\ Radiotherapy and Oncology Centre \\ Ahmadu Bello University Teaching Hospital, Shika-Zaria \\ E-mail: sadewuyi2003@yahoo.com
}

\begin{abstract}
Background:

Prostate cancer is widely known to vary substantially in aggressiveness. There is also significant potential morbidity associated with aggressive curative treatment. So, there is a tremendous interest in the development of prognostic factors that could guide management decisions that allow treatment to be tailored and individualized.
\end{abstract}

This review seeks to identify the traditional tumour related prognostic factors, emerging biomarkers of prognostic importance as well as patient and environment related prognostic factors in prostate cancer.

\section{Method:}

The PubMed database was searched for all existing literature. Also, references were made to some bibliographies cited in the available literature.

\section{Conclusion:}

Majority of prostate cancer may not progress to clinically significant disease. Prognostic factors have therefore become important to predict tumour progression and eventual outcome.

Keywords: prostate cancer, prognostic factors, tumour makers, biological markers.

\section{Introduction}

Prognosis refers to forecast of possible course and outcome of a disease. Bailey ${ }^{1}$ defined prognosis as a reasoned forecast concerning the course, pattern, progression, duration and end of a disease. For a patient, it reflects the chances of survival.

Prognostic factors are variables that account for some of the heterogeneity associated with the expected course and outcome of a disease ${ }^{2}$. These factors are important in understanding of the natural history and course of a disease as well as in predicting treatment outcome.

The incidence of Prostate cancer is increasing in this environment. With ageing population, improvement in economic situation and changing social lifestyles, it is expected that prostate cancer will be very common male malignancy in nearest future. Similarly, the socio demographics factors in prostate cancer are changing, with younger males affected and aggressive disease seen in this environment compared with the pattern in developed world.

The implication of the variables is that treatment must be individualized for each patient; no single type of protocol will satisfy the various tumour biology and variables. Similarly, for better treatment outcome and survival, the concept of multidisciplinary and multi modality approach to prostate cancer cannot be overemphasized.

Based on the clinical findings and on the variables available, the treatment should be tailored to meet the patient's needs holistically. In other words, the treatment should ideally be individualized. For example, which class of patients will benefit from watchful waiting, conservative management, radical surgery, surgical castration, is identified and 
complications avoided. Similarly, it will form a basis for which chemotherapy regimen are used on evidence-based medicine. It will reduce the common problems of inadequate treatment, over treatment, inadequate dosages, and delay in referral for radiotherapy and chemotherapy.

Prognostic factors become even more important in prostate cancer where a large number of cases are unlikely to become clinically manifest and aggressive treatment carry significant potential morbidity. Stanford and colleagues ${ }^{3}$ in a study of complications after surgical therapy for localized disease in an unselected population-based cohort reported that at more than 18 months after radical prostatectomy, $8.4 \%$ of men were incontinent and $41.9 \%$ reported their sexual performance as a moderate to large problem. It is therefore important to apply prognostic factors in making prostate cancer treatment decisions.

Several independent prognostic factors have been proposed for prostate cancer. See Table 1.

These may be classified into:

1. Tumour related prognostic factors.

2. Patient related prognostic factors.

3. Environment (including finaneial) retated prognostic factors.

\section{Tumour related prognostic factors}

\section{Histological features}

\section{a. Tumour type}

The uncommon histologic variants of prostate cancer can be associated, with rapid progression ${ }^{4}$. The presence of small cell carcinoma and poorly differentiated tumours expressing neuroendocrine makers are harbinger of poor prognosis.

Mucinous carcinomas, rarely respond to hormonal therapy and often cause bone metastasis 5 . Adenoidcystic carcinoma is also associated with distant metastasis at diagnosis ${ }^{6,7}$. Small cell and neuroendocrine cancer are associated with a uniformly poor prognosis ${ }^{8}$.

\section{b. Tumour grade}

The microscopic grade of a prostate cancer correlates significantly with the local extent of the disease, response to various therapies and overall disease outcome $\mathrm{e}^{9,10}$.
The histological Gleason score of the adenocarcinoma of the prostate is a good and an established prognostic factor. Univariate and multivariate analyses of prognosis in prostate cancer almost always identify Gleason grade as one of the most significant predictors of patient outcomes $^{11}$. Two important studies ${ }^{12,}{ }^{13}$ have demonstrated a good correlation between the prognosis of prostate cancer and Gleason score.

\section{c. Tumour stage}

The pathological stage of prostate cancer is one the most important independent prognostic factor. Most often, treatment is determined by stage of disease. The presence of perineural invasion in the needle biopsy specimen has been reported to be specific marker for capsular penetration of the tumour in prostatectomy specimen ${ }^{14}$. Seminal vesicle invasion is associated with high grade, lymphatic metastasis and poor prognosis ${ }^{15}$. Also, positive margin of resection significantly affect disease outcome and correlate with high pre-operative PSA, high grade and poor prognosis ${ }^{16}$. The presence of nodal metastasis is associated with significant tumour progression and poor prognosis ${ }^{17}$. Bone, liver and other visceral metastases, often herald progression to andatoutcome.

\section{Tumour-specific protein /molecular markers}

\section{A. PSA}

The values of total PSA (tPSA), free (fPSA) and PSA complexed to $a_{1}$-antichymotrypsin (PSAACT) are all independent prognostic factors of prostate cancer ${ }^{18}$. Serum PSA level is a strong prognostic determinant of outcome following radiotherapy for prostate cancer and appears to add prognostic information independent of tumour stage and grade ${ }^{19}$.

Also, after radical prostatectomy a rising serum PSA level almost always precedes clinical recurrence of the cancer ${ }^{20}$. The clinical significance of pretreatment serum PSA value studied by Kariyama and colleagues ${ }^{21}$ revealed that serum PSA can be used to predict the stage and prognosis of prostate cancer.

In particular, pre-operative serum PSA levels are highly predictive of tumour burden and risk of recurrence after radical prostatectomy ${ }^{22}$.

\section{b. DNA ploidy}

Many retrospective studies have shown that aneuploid DNA content in prostate cancer 
independently predicts a poor prognosis ${ }^{23,}{ }^{24}$. Aneuploidy has generally been associated with poor differentiation and more aggressive tumour in comparison with diploid lesion and this holds for prostate cancer. About $85 \%$ of patients with organ confined prostate cancer treated with radical prostatectomy have diploid tumours.

\section{c. Microvessel density (MVD)}

Tumour growth beyond a certain size requires angiogenesis. Tumour angiogenesis correlates with poor outcome in prostate cancer ${ }^{25}$. Significantly higher microvessel counts have been obtained in areas of adenocarcinoma than in benign tissues of radical prostatectomy specimen. Bore and colleagues ${ }^{26}$ demonstrated that MVD was a significant predictor of shorter disease-specific survival in the entire cancer population.

\section{Tumour suppressor genes}

\section{a. $\quad$ P53}

Increase expression of P53 is associated with point mutations of one allele of P53 gene and loss in others. Thomas and colleagues ${ }^{27}$ as well as Shurbaji and colleagues ${ }^{28}$ following immunohistochemical evaluation of P53 gene, chronicled that mutations of P53 genes are involved in the carcinogenesis of prostate cancer. They also noted that it is associated with an aggressive subset of prostate cancer.

\section{b. PTEN/AKTI-1}

The PTEN (Phosphatase and Tensin homolog detected from chromosome 10), a tumour suppressor gene is deleted or mutated in a wide variety of malignant neoplasms and also in prostate cancer $^{29,30}$. Loss of expression of PTEN has been associated with down-regulation of cyclindependent kinase inhibitor, $\mathrm{P} 27$ and poor prognosis with increasing tumour grade and stage of prostate cancer $^{31}$.

\section{Oncogene}

\section{a. Her-2/neu (Cerb-b2) gene}

The presence of Her-2/neu gene amplification or over expression is associated with poor outcome ${ }^{32}$, ${ }^{33}$. Assessing for Her-2/neu is a routine practice in breast cancer but not so in prostate cancer. This is because unlike in breast cancer, randomized clinical trial (RCT) using Her-2/neu monoclonal antibody- trastuzumab (Herceptine) has not shown significant response in prostate cancer ${ }^{34}$.

\section{Androgen receptor (AR)}

Androgen receptor loss or mutation and lack of benefit from hormonal treatment have been associated with high grade disease and poor outcome. AR expression can be heterogeneous in prostate cancer, which reflects AR gene instability ${ }^{35}$. Mutation in the coding region of the AR gene has been found both in the untreated prostate cancer and hormone refractory prostate cancer (HRCP). Segawa and colleagues ${ }^{36}$ demonstrated that AR expression was significantly lower in adenocarcinoma than in non-tumour prostate tissues. They found that there is significant correlation between progression free survival and AR expression.

Similarly, the results of Miyoshi and colleagues ${ }^{37}$ showed that AR expression level in HRCP specimen was significantly lower than that in previously untreated prostate cancer or benign prostatic hyperplasia (BPH) specimens. The greater AR heterogeneity pattern seen in HRCP may be due to greater genetic instability in such tumours. In other words the growth factors may exhibit their effect via crosstalk with $\mathrm{AR}^{38}$. Therefore $\mathrm{AR}$ heterogeneity may be used as an independent predictor of response and sign of disease progression ${ }^{39}$.

\section{Cell proliferation markers}

\section{a. $\mathrm{Ki}-67$}

$\mathrm{Ki}-67$ is one of the several cell-cycling-regulating proteins. It is a DNA-binding protein, which is expressed in all phases of cell cycle but undetectable in resting cells ${ }^{40}$. Ki-67 index is higher for carcinomas than for hyperplastic glands. Within carcinomas, ki-67 indices in patients with metastatic disease were significantly higher than in those without metastasis.

\section{b. S-phase fraction.}

$\mathrm{S}$-phase fraction (SPF) is the proportion of cells in the S-phase of the cell-cycle. High SPF is associated with rapid tumour proliferation, shorter overall survival and shorter time to local progression and metastasis in clinically localized prostate cancer ${ }^{41}$.

\section{Cell adhesion molecules}

\section{a. E-cadherin}

E-cadherin is an important adhesion molecule in epithelial cells. Reduction or loss of E-cadherin level has been found in malignant prostate specimen ${ }^{42}$. Patients showing low immunohistochemical expression of E-cadherin 
have on average shorter survival than patients with higher immunohistochemical expression.

\section{Patient related factors}

\section{Age}

The role of age of the patient as a significant prognostic factor in prostate cancer engenders debates $^{43,44}$. Harold and colleauges ${ }^{45}$ in analysis of 567 patients undergoing external beam radiotherapy (EBRT) found that age more than $65 \mathrm{yr}$ was a significant predictor of distant metastasis and poor outcome at 15yr. Obek and colleauges ${ }^{46}$ suggested that young age might be an independent favorable prognostic factor for disease recurrence after radical prostatectomy. Freedland and colleauges ${ }^{47}$ also found that young men had more favorable outcomes after radical prostatectomy than older men, which made younger patients suitable subjects in screening.

\section{Race}

The highest prostate cancer incidence and mortality have been reported in blacks. Race is a well known risk factor for developing prostate cancer. However this disease also behaves differently in men of different races. Whether this is due to patient related factors or to external factors is not clear yet.

Dasal and colleagues ${ }^{46}$ suggest that racial difference between Blacks and Caucasians in survival prognosis for prostate cancer was to a large extent the result of socio-economic status.

\section{Co-morbidities and Karnofsky Performance Status}

Diabetes mellitus, obesity, cardiac failure, hypertension, bleeding disorders, Karnofsky Performance Status are established poor independent outcome parameters in cancer patients.

Karnofsky Performance Status (KPS):

- $\mathbf{1 0 0 \%}$ Normal; No complaints

- $\mathbf{9 0 \%}$ Normal activities; minimal signs or symptoms

- $\mathbf{8 0} \%$ Normal activities with effort. Some symptoms

- $\mathbf{7 0 \%}$ Caring for self; unable to work

- $\mathbf{6 0 \%}$ Needs occasional assistance but able to care for most needs

- $\mathbf{5 0 \%}$ Needs considerable assistance and frequent medical care

- $\mathbf{4 0 \%}$ Disabled; needs special care

- $\mathbf{3 0 \%}$ Severely disabled; needs hospital care
- $\mathbf{2 0} \%$ Very ill. In hospital; needs supportive care

- $10 \%$ Moribund.

- $0 \%$ Dead.

As depicted above, the lower the KPS, the worse the patient's outcome, not only in prostate cancer, but in all malignancies.

\section{Environmental factors}

\section{Socio-economic status}

Studies have found reduced access to healthcare due to poor socio-economic status and this contributes to higher mortality rate from prostate cancer ${ }^{49,50}$.

It has been shown that among patients of high socioeconomic class, even the elderly with low-risk prostate cancer receives some form of treatment. Financial constraint has been found to contribute to late presentation, poor treatment compliance, loss to follow up and poor treatment outcome in cancer patients in our environment ${ }^{53}$.

\section{Access to quality health car.}

This is influenced by myriads of factors including the socio-economic factors, cultural practices, demography and national health-care policies. The impact is not only on outcome of prostate cancer but many disease entities. The National Health care policy which is absent in most developing countries influence the availability of facilities and expertise.

Table 1: Table showing important prognostic factors in Prostate Cancer

\begin{tabular}{|l|l|l|l|}
\hline & $\begin{array}{l}\text { TUMOUR } \\
\text { RELATED }\end{array}$ & $\begin{array}{l}\text { HOST } \\
\text { RELATED }\end{array}$ & $\begin{array}{l}\text { ENVIRONMENT } \\
\text { RELATED }\end{array}$ \\
\hline ESSENTIALS & $\begin{array}{l}\text { TNM Categories } \\
\text { PSA }\end{array}$ & & \\
& Gleason Score & & \\
& & & \\
\hline
\end{tabular}

\begin{tabular}{|c|c|c|c|}
\hline ADDITIONAL & $\begin{array}{l}\text { PSA Velocity } \\
\text { PSA Doubling Time } \\
\% \text { Positive Biopsy } \\
\text { DNA Ploidy } \\
\text { Margin Status }\end{array}$ & $\begin{array}{l}\text { Age } \\
\text { Comorbidity } \\
\text { Performance } \\
\text { Status }\end{array}$ & $\begin{array}{l}\text { Access to Care } \\
\text { Quality of Care }\end{array}$ \\
\hline $\begin{array}{l}\text { NEW AND } \\
\text { PROMISING }\end{array}$ & $\begin{array}{l}\text { Ki } 67 \\
\text { MIBI } \\
\text { Microvessel Density }\end{array}$ & & \\
\hline
\end{tabular}

Reference

NCCN Clinical Practice Guidelines in Oncology:

Prostate cancer 2005

\section{Conclusion}

A large number of prostate cancers may never progress to clinically significant disease. Tumour related preoperative and postoperative prognostic 
factors are important to predict prostate cancer outcome. The classical tumour related prognostic factors in prostate cancer are TNM stage, the serum PSA level and Gleason score. Other valuable tumuor related prognostic factors like biomarkers (DNA ploidy, MVD, P53, PTEN/AKTI-1, AR, Ki67, E-cadherin, S-phase fraction) remains to be applied routinely in clinical practice despite extensive literature that support their usefulness. Apart from tumour related factors, prognosis is also determined by the patient's personal data related to age, race, co-morbidities and even his individual life expectancy.

The health provider and national health policies as well as access to quality health-care are also important prognostic factors, even more so in our sub-region.

The efforts to provide optimal health-care for everybody everywhere may be seen as utopia, but somehow it does not seem right that someone's socio-economic or demographic situation affect his prognosis significantly. Yet, this happens often in our country and there is need for change.

\section{References}

1. Bailey JA. Concise dictionary of medical-legal terms. The parathion publishing Groups, New York1998.

2. Denis L, Bartsch G, Khourys S (eds). The prostate cancer. Health Publications, Paris2003

3. Stanford JL, Feig Z, Hamilton AS. Urinary and sexual problems after radical prostatectomy for clnically localized prostate cancer. The prostate cancer outcome study. JAMA.2000; 283: 354360.

4. Randolph TL, Ameri MB, Ro JY. Histologic variants of adenocarcinoma and other carcinomas of the prostate: Pathologic criteria and clinical significance. Mod Pathol1997; 10: 612-629.

5. Epstein JI, Lieberman PH. Mucinous adenocarcinoma of the prostate gland. Am J Surg Pathol1985; 9: 299 308.

6. Young RH, Strigley JR, Amin MB. Tumours of the prostate gland, seminal vesicles, male urethra and penis. Washington, DC: Armed forces institute of pathology2000:217 254 .

7. Kuhajda FP, Mann RB. Adenoidcystic carcinoma of the prostate: A case report with immunoperoxidase staining for prostate-specific acid phosphatase and prostatespecific antigen. Am J Pathol1984; 81:257 260.

8. Ro JY, Tetu B, Ayala AG. Small cell carcinoma of the prostate: Immunohistochemical and electron microscopic studies of 18 cases. Cancer1987; 59: 977 982.
9. Tarone RE, Chu KC, Brawley OW. Implications of stage-specific survival rates in assessing recent declines in prostate cancer mortality rates. Epidemiollogy2000; 11: 167170 .

10. Montironi R, Mazzucchelli R, Marshall JR. prostate cancer prevention; review of target populations, pathological biomarkers and chemopreventive agents. J Clin Pathol1999; 52: 793803.

11. Thompson GJ, Albers DD, Broders AC. Unusual carcinomas involving the prostate gland. J urol1953; 69: 416.

12. D'Amico AV, Wu Y, Chen MH. Pathologic findings and prostate specific antigen outcome after radical prostatectomy for patients diagnosed on the basis of a single microscopic focus of prostate carcinomas with a Gleason score 7. Cancer 2000; 89: 18101817.

13. McNeal JE, Villers AA, Redioline EA. Histologic differentiation, cancer volume and pelvic lymph node metastasis in adenocarcinoma of the prostate. Cancer1990; 66: 12251233.

14. Bastacky SI, Walsh PC, Epstein JI. Relationship between perineural tumour invasion on needle biopsy and radical prostatectomy capsular penetration in clinical stage B carcinoma of the prostate. Am J Surg Pathol1993; 17: 336341.

15. Ohori AM, Scardino PT, Lapin SL. The mechanism and prognostic significance of seminal vesicles involvement by prostate cancer. Am J Surg Pathol 1993; 17: 1252 1261.

16. Epstein JI, Bizo VG, Walsh PC. Correlation of pathologic findings with progression after radical retropubic prostatectomy. Cancer 1993; 71:3582 3593.

17. Herman CM, Wilcox GE, Kattan MW. Lymphovascular invasion as a predictor of disease progression in prostate cancer. Am J Surg Pathol 2002; 2 4: 859863.

18. Bjork T, Lilja $\mathrm{H}$, christensson $\mathrm{A}$. the prognostic value of different forms of prostate cancer specific antigen and their ratios in patients with prostate cancer. BJU Int 1999; 10211027.

19. Zagars GK. Prostate specific antigen as a prognostic factor for prostate cancer treated by EBRT. Int J Ratiat Oncol Biol Phys 1992; 23: 4347.

20. Pound CR, Partin AW, Eisenberger MA, Chan DW, Pearson JD, Walsh PC. Natural history of progression after PSA elevation following radical prostatectomy. JAMA1999; 281: 15911597.

21. Kariyama M, Obata K, Miyagawa Y, Nishikawa E, Koide T, Takeda A. serum prostate specific antigen values for the prediction of clinical stage and prognosis in patients with prostate cancer: an analysis of 749 cases. Int J Urol 1996: 3; 462467. 
22. Hull GW, Rabbani F, Abbas F, Wheeler TM, Kattan MW, Scardino PT. Cancer control with radical prostatectomy alone in 1000 consecutive patients. J Urol 2002

23. Ross JS, Nazeer T, Church K. combination of HER$2 /$ neu oncogene expression to tumour grade and DNA content analysis in the prediction of prostate carcinoma metastasis. Cancer 1993; 72: 30203023.

24. Winkler HC, Rainwater LM, Myer RP. Stage D1 prostate carcinoma: significance of byflow cystometry. Mayo Clin Proc1988; 63: 103112.

25. Peters JM, Miles BJ, Kubus JJ. The prognostic significance of the nuclear DNA content in localized prostatic adenocarcinoma. Anal Quant Cytol Histol 1990; 12:359 365 .

26. Weidner N, Caroll PR, Flax J. tumour angiogenesis correlation with metastasis in invasive prostate carcinoma. Am J Pathol1993; 143: 401409.

27. Bore M, Offersen BV, Nerstrom B, Overgaard J. microvessel density predicts survival in prostate cancer patients subjected to watchful waiting. Br J cancer 1998; 78: 940944.

28. Thomas DJ, Robinson M, King P, Hassan T, Charlton R, Martin J. P53 expression and clinical outcome in prostate cancer. Br J Urol1993; 72: 778781.

29. Shurbaji Ms, Kalbfleisch JH, Thurmond TS. Immunohistochemical detection of P53 protein as a prognostic indicator in prostate cancer. Hum pathol1995; 26: 106109.

30. Graff JR, Konicek BW, McNulty AM. Increased AKT activity contributes to cancer progression by dramatically accelerating prostate tumour growth and diminishing p27 Kip1 expression. J Biol Chem2000; 273:24500 24505.

31. Mcmenamin ME, soung P, Perera S. loss of PTEN expression in paraffin-embedded primary prostate cancer correlation with high Gleason score and advanced stage. Cancer Res 1999; 59: 42914296.

32. Yang G, Ayala G, Marzo AD. Elevated skp2 protein expression in human prostate cancer: association with loss of the cyclidin-dependent kinase inhibitor p27 and PTEN and with reduced recurrence free survival. Clin Cancer Res 2002; 8:3419 3426.

33. Signoretti S, Montironi R, Manola J. HER -2-neu expression and progression toward androgen independence in human prostate cancer. J Natl cancer Inst2002;92: 19181925.

34. Sanchez KM, Sweeney CY, Mass R. Evaluation of HER-2-neu expression in prostate adenocarcinoma: a request for a standardized, organ specific methodology. Cancer2002; 95: 16501655.
35. Morris MJ, Reuter VE, Kelly WK. HER-2/neu profiling and targeting in prostate carcinomas. Cancer2002; 94: 980986.

36. Sadi MV, Barrack ER. Image analysis of androgen receptor immunostaining in metastatic prostate cancer. Proc Natl Acad Sci 1992; 89: 63196323.

37. Segawa N, Mori I, Utsunomi Y, Nakamura M, Shan L. prognostic significance of neuroendocrine differentiation, proliferation activity and androgen receptor expression in prostate cancer. Pathol Int 2001; 51:452 459 .

38. Miyoshi $\mathrm{Y}$, Ishiguro $\mathrm{H}$, Uemura $\mathrm{H}$, Fujinami $\mathrm{K}$, Miyamoto. Expression of AR associated protein55 (ARA55) and androgen receptor in prostate cancer. Prostate 2003; 56:280 286.

39. Culig Z, Hobisch A, Cronaver MV, Radmayr C, Trapman J. androgen receptor activation in prostate tumour cell lines by insulin-like growth factor-1, keratinocyte growth factor and epidermal growth factor. Cancer Res1994; 54: 54745478.

40. Sadi MV, Barrack ER. Image analysis of androgen receptor immunostaining in metastatic prostate cancer. Heterogeneity as a predictor of response to hormonal therapy. Cancer1993; 71:2574 2580.

41. Gerdes J, Schwal U, Lemke H, Stein H. production of a mouse monoclonal antibody reactive with a human nuclear antigen associated with cell proliferation. Int $\mathbf{J}$ Cancer1983;31:13 20.

42. Astrom L, Weimarc KA, Aldenborg F, Delle U, Hanson C. S-phase fraction related to prognosis in localized prostate cancer. No specific significance of chromosome 7 gain or deletion of 7q31.1. int cancer 1998; 79: 553 559.

43. Umas R, Schalken JA, Aalder TW, Carter BS, Karthaus HF, Schaafsma HE. Expression of the cellular adhesion molecules E-cadherin is reduced or absent in high-grage prostate cancer. Cancer Res1992; 52: 51045109

44. Austin JP, Convery K. age-race interaction in prostate adenocarcinoma treated with external beam irradiation. Am J Clin Oncol1993; 16: 140145.

45. Gronberg H, Damber JE, Jonsson H, Lenner P. patient age as a prognostic factor in prostate cancer. J urol1994; 152: 892895 .

46. Herold DM, hanlon AL, Morsas B, Hanks GE. Agerelated prostate cancer metastasis. Urology1998; 51: 985990.

47. Obek C, Lai SS, Civantos F, Sloway MS. Age as a prognostic factor for disease recurrence after radical prostatectomy. Urology1999; 54: 533538. 
48. Freedland SJ, Presti JC, Kane CJ, Aronson WJ, Terris MK, Dorey F. do younger men have better biochemical outcome after radical proatectomy? Urology 2004; 63: 518522.

49. Hall WH, Jani AB. The impact of age and comorbidity on survival outcomes and treatment pattern in prostate cancer. Prostate cancer 2005; 8: 2230.

50. Dayal HH, Polissar L, Dahlberg S. race, socioeconomic status and other prognostic factors for survival from prostate cancer. J Natl cancer Inst1985; 74: $1001-1006$.
51. Jemal A, Ward E, Wux. Geographic patterns of prostate cancer mortality and variations in access to medical care in US. Cancer epidemiolol Biomarkers Prev2005; 14: 590595.

52. Chan JM, Joy RM, Caroll PR. The relative impact and future burden of prostate cancer in the US. J Urol2005; 172: 1317 .

53. Adewuyi SA, Shittu SO, Rafindadi AH. Sociodemographic and Clinicopathologic Characterization of Cervical Cancer in Northern Nigeria. Eur. J. Gynaec. Oncol (EJGO). 2008; vol. 29(1):61 64. 